\title{
Beyond welfare chauvinism and deservingness. Rationales of belonging as a conceptual framework for the politics and governance of migrants' rights
}

\begin{abstract}
This article argues that the politics and governance of migrants' rights needs to be reframed. In particular, the terms "welfare chauvinism", and deservingness should be replaced. Using a qualitative transnational case study of policymakers in Poland and the UK, we develop an alternative approach. In fine-grained and small-scale interpretive analysis, we tease out four distinct rationales of belonging that mark out the terms and practices of social membership, as well as relative positions of privilege and subordination. These rationales of belonging are: temporal-territorial, ethno-cultural, labourist, and welfareist. Importantly, these rationales are knitted together by different framings of the transnational contexts, within which the politics and governance of migration and social protection are given meaning. The rationales of belonging do not exist in isolation, but in each country, they qualify each other in ways that imply different politics and governance of migrants' rights. Taken together, these rationales of belonging generate transnational projects of social exclusion, as well as justifications for migrant inclusion stratified by class, gender and ethnicity.
\end{abstract}

Keywords: welfare chauvinism, migrant rights, deservingness, migration, EU free movement, governance, UK, Poland. 


\section{Introduction}

The rights of migrants, and their access to social and economic resources, are decided the complex junction between the politics and governance of migration, on the one hand, and the politics and governance of welfare, on the other. How migration is governed, and how migrants' welfare is governed, are closely, but contingently, related (Ataç and Rosenberger 2019; Mayblin 2019). At the same time, particular governing practices depend on, and are reproduced by, political discourse and meaning-making, that establish what can and should be governed, how and with what effects (Carmel, 2019).

Two key concepts are generally used in social policy literatures to explore these relationships: 'welfare chauvinism', and 'deservingness'. In this article, we argue that neither concept provides an adequately refined tool for untangling the politics of, and policies for, migrants' social rights, and their normative contestation. Furthermore, several recent qualitative studies show the complex assumptions and purposes that underpin expression of values measured in attitude surveys (cf. Keskinen 2016; Jørgensen and Petersen 2016). 'Welfare chauvinism' is too ambiguous, and 'deservingness' is a binary concept, so cannot easily be operationalized to capture this complexity. Both concepts reproduce and reify methodologically nationalist assumptions about social rights and migration, rather than attending to the more complex transnational politics and governance of migration and social security in practice.

Drawing on sociological theorising in migration studies, in this article, we are able to propose an alternative conceptual framework to explain the multi-dimensional assumptions, contexts and dynamics that shape the politics and governance of migrants and their social rights. Discussing the 'politics of belonging' (Yuval-Davis 2011); transnational citizenship and community (Faist 2000; Amelina 2019); and 'communities of value' (Anderson 2013), we can identify a range of reasonings about status, rights and membership that provide organisational logics to discriminate between those who belong, how far they belong, and under which conditions. Taken together, the literature indicates that these reasonings are organised around ethno-cultural, temporal-territorial, welfareist, labourist and transnational logics. We call these 'rationales of belonging'.

Empirically, the article explores these ideas of how migrants' social rights are justified and regulated in practice. It presents a fine-grained, analysis of a small-scale transnational case study of elite British and Polish civil servants and experts. The empirical analysis was conducted abductively. Starting from an open-ended, inductively-framed interest in policy experts' understandings of welfare regulations and EU migration, the analysis was elaborated step-wise by iteratively engaging with conceptual literatures to shed light on participants' interpretations. (For clarity of narration, however, we present our discussion of the literatures first, before exploring how 'rationales of belonging' were reflected in our empirical case.)

We closely examine the everyday, 'taken-for-granted' political articulation of social rights and EU mobility by those responsible for its governance. These elite policymakers articulated complex, multi-dimensional positions and justifications about the regulation of social security in general, and for migrants in particular (in our case, 'free moving' EU citizens). They did so 
through implicit assumptions and explicit reasoning that reflected distinct, salient 'rationales of belonging'. Their use of these rationales signalled distinctions between migrants and citizens and specific, limited and politicised social rights for migrants, as well as hierarchies among migrants. Participants explicitly articulated these rationales in the wider political economy and socio-geographical context of welfare, politics and migration in each country. We identified one dominant rationale (different in each country-case), that in each case was also nuanced by reference to two others. We also found that while participants in both Poland and the UK articulated 'welfareist' and 'temporal-territorial' rationales of belonging, these rationales were expressed differently in each country.

From this inductive/abductive, qualitative analysis, we argue that 'rationales of belonging' is a valuable conceptual framework that can be developed and applied for further empirical research. We conclude with some reflections on its applicability for further exploration of attitudes and values of migrants and their relationship to welfare.

\section{Welfare chauvinism, deservingness, and belonging as alternative conceptualisations}

\section{Welfare chauvinism}

'Welfare chauvinism' has commonly been used as a heuristic in studies of political attitudes to the social entitlements of migrants. Surprisingly, however, given its use in a range of studies, titles of books and articles, the concept of 'welfare chauvinism' is underspecified for this task.

Goul-Andersen and Bjørklund (1990) coined the term almost in passing. They summarily defined it as the prioritisation of 'looking after one's own', and their whole discussion about the term makes barely a page of text, that includes two tables (pp. 210-12). Their article sought to explain the sustainability and distinctiveness of far-right nativism and populist politics since the early 1970s in Denmark and Norway. 'Welfare chauvinism' was the key common characteristic, for which the authors cited attitudinal data showing nativist party supporters' hostile attitudes towards aid to 'developing countries' (for Denmark) as equivalent to protectionist attitudes to provision of 'welfare' to 'foreigners' domestically ( $p$. 211) (for Norway). Specifically, these 'welfare chauvinist' attitudes did not express racist views (p. 212). They argued that this so, even though the common identification of 'foreigners' and 'developing countries' with Blackness is indeed precisely what unites these attitudes, and also what distinguishes these nativist parties from their immediate post-Nazi predecessors (see Kiskanen, 2016, pp. 2-3). In its conceptual origins, then, 'welfare chauvinism' better described racist attitudes than anti-migrant ones.

Recent studies have used welfare chauvinism as an organising idea or reference point for empirical studies. In doing so, they clearly show the variety of meanings that 'welfare chauvinism' can contain and conceal (Kiskanen 2016; Greve 2019, pp. 30-33). Migration research shows that the legal status of migrants directly affects the regulation of their rights and access to resources, including social rights, and how these are justified (cf Carmel and Paul 2013; Koopmans 2010). Yet 'welfare chauvinism' might refer to diverse groups of migrant (Jørgensen and Thomsen 2016), or different categories of benefit with a range of entitlement 
mechanisms, more or less relevant to migrants (Ennser-Jedenastik, 2017; Jensen and Petersen, 2017). Furthermore, the politics and governance of migrants' status, rights, and attitudes towards them, are in practice racialised, classed and gendered (see Koostra 2016; Kremers 2016) in ways not captured by the generality and ambiguity of the concept. Kiskanen (2016) proposes the additional terms 'welfare nationalism' and 'welfare exclusionism' to identify non-racist political discourse, but these also bundle together a range of attitudes, rather than parsing out their component dimensions and diversity that is relevant to our purposes. They do not address questions of how attitudes intersect with policy and the regulation of social rights.

\section{Deservingness}

The other key conceptual tool for empirically explaining the politics of migrants social rights is 'deservingness'. The distinctions between deserving/undeserving are produced in policy and in political discourse, benefit categories, organization of entitlements and conditionality (Clarke, 2005; Schneider and Ingram, 2005). Through policy and law, deservingness accords social legitimacy on benefit recipients and on categories of behaviour (Mau and Mewes 2013; Svallfors, 2014; van Oorschot et al, 2017). However, as Koostra (2016, p. 326-8) shows, discussing deservingness of migrants in relation to access to social benefits or rights makes a category error. Surveys that ask whether migrants deserve benefits de facto ask about the legal personhood of the status 'migrant', and the moral economy of belonging that is associated with that mobility, rather than the moral economy of deservingness on the basis of behavior or socio-economic entitlement.

Attitudes towards migrants' claims are based on emotional and ideologically-framed feelings of identification, value, assumptions about 'ways of being' and the worth of their status as migrants, not as people claiming social rights (Carmel and Cerami 2011; Osipovič, 2015). Public discourse and governance selectively privileges the rights of particular kinds of workermigrant, or asylum-seeker, who might fit different deservingness criteria more or less well, not because of their behaviour or entitlements, but because of their legal categorization or ethnic identity (Koostra, 2016, esp. pp. 330-2; Sainsbury, 2012; Mayblin 2019). Recognition of migrants' rights can be - and in practice often is - articulated in intricate webs of overlapping policies, conditions, and justifications that generate complex forms of stratification and access to rights (Carmel and Paul 2013; also Bruzelius, 2019; Heindlmaier and Blauberger 2017). Its expression in both political discourse and policy is classed, gendered and ethnicised (cf Shutes and Walker 2018; Amelina and Lutz 2019). As such, 'deservingness' disguises the complexity of the intersecting moral economies of welfare and migration in politics and governance. This complexity cannot be captured in binary deserving/non-deserving categorisations.

\section{Belonging}

Nira Yuval-Davis and Floya Anthias elaborated a distinctive political sociology of migration, showing how intersecting institutions, 'organised around the intentionality of control with a given apparatus of enforcement', are used to determine those who belong, and, most importantly, on what conditions (Anthias and Yuval-Davis 1989 p.6). Their approach accommodates both the governance of rights and the political discourses that sustain them. 
In this section we examine their work alongside further conceptual elaborations that explore the place of welfare, work and transnationalism in the political sociology of migration. In synthesis, we identify the conceptual outlines of five 'rationales of belonging' that underpin political discourse, action and governance of migrants and migration.

Ethno-cultural: The governance of migration and the rights of migrants has long been tied to claims of ethno-cultural homogeneity, particularly, but not only, in societies that frame themselves as destination countries, or 'countries of immigration'. Ethno-cultural belonging rests on collective imaginaries to create shared emotional attachments to, and claims on, 'the nation' (Anderson, 1991; Gellner, 2010). It assumes a durable production and protection of national identity as a feeling of belonging (Guibernau, 1996, 2007; Özkirimli, 2010), and in 'countries of emigration', diaspora communities can play an important role (Lavie, 1996). In Europe, ethno-cultural belonging implicitly or explicitly constituted through Whiteness has been central to the organisation and management of migration (Bhambra 2015; de Genova 2015). Women have historically played a special role in the reproduction of this notional nation biologically, culturally and symbolically (Yuval-Davis, 1996), as reflected in social norms and legislation relating to sexual relationships, sexuality and procreation. Ethno-culturally and racially pure women become responsible for the purity of the nation's blood which should not be contaminated (Anthias and Yuval-Davis, 2005) and ethno-cultural politics of belonging is usually associated with ius sanguinis citizenship regulation.

Temporal-territorial: The national state is existentially territorial, that is, it has a distinctively spatial dimension, even if the boundaries of that territory are frequently contested, challenged, or rendered indeterminate through colonial projects (Hansen and Jonson 2014; Carmel 2019). Seen as homeland (Yuval-Davis, 1997), rights to be present in a physical space are subject to temporal-territorial politics of belonging, a 'racialisation of exclusion and inferiorization that are the outcome of the relative new presence of particular people and collectives in particular places [...]' (Yuval Davis 2011 p.99; Anthias and Yuval-Davis 2005). Temporal-territorial belonging can sanction the political claims of indigenous peoples for emancipation, but historically it has been more often used to occlude the violence of settler colonialism, and it can undermine claims for diasporic belonging that are marked by territorial absence. Regulation of migrants' social, political and civil rights has strong temporal dimensions (Griffiths, 2016) and temporal-territorial belonging is usually associated with ius solis citizenship regulations. This rationale highlights the fundamental importance of 'rights to reside' and the temporal regulation of migrants' rights status and membership (Bruzelius 2018; Carmel, Sojka, Papiez 2019) neither of which are accessible with concepts of welfare chauvinism or deservingness, even though they figure significantly in public attitudes (cf Greve 2019, pp. 142-5).

Welfareist: The association of ethno-cultural nationhood with sexual and social reproduction is also integral to the gendered (and in some cases, eugenicist) foundations of national welfare states. These define the terms of social resource entitlement through the regulation of norms, social categorisations and behavioural conditions. In doing so, they establish terms, conditions and degrees of belonging, regulate 'problematic populations', and stratify, discipline and reward privileged social groups and preferred behaviours (Runfors and Fröhlig 2019). So, although there may be ideas and attitudes to migrants' deservingness that are shaped by the 
characteristics of benefit conditionality (e.g. via need or contributions) (Ennser-Jedenastik 2017), welfare systems do not map directly onto the attitudes or 'policy imaginary' (Mayblin 2016) of migration governance, or designate legitimate entitlement. This is because entitlement for migrants is always tied up with the categorisation of their a priori legal status: as a high skill, temporary, family dependant, or refugee migrant, for example. Welfareist rationales belonging therefore 'cuts across' the acceptability of behaviours of migrants (the idea of 'deservingness'), and is used to directly govern migrants' migration, as much as their claims to welfare (Ataç and Rosenberger, 2019; Mayblin, 2019).

Labourist: Bridget Anderson (2013) shows that defining migrants as non-citizens, and the indigent and unemployed as failed citizens, also conjointly serves to create the boundaries of a (national) 'community of value'. The internal ordering of social belonging that valorises 'work' can merge into social belonging for (particular kinds of) 'workers'. This labourist rationale then relies on definitions and assumptions about who or what is a worker, or how particular forms of work count towards belonging (e.g. some work is only suitable or men or women; or perhaps 'employment' is an activity for masculine belonging) (Soysal 2012). The labourist rationale of belonging can be related to welfareist belonging, but need not be. The non-worker migrant and the non-worker citizen may share classed, ethnicised and gendered characteristics that are stigmatised, Other, unentitled (Bauman, 2011).

Transnational: This rationale of belonging counters the methodologically nationalist assumptions in 'deservingness' and 'welfare chauvinism' conceptual frames. Belonging is not always experienced, regulated, or understood, in statist or national frames. Studies of belonging indicate that migrants themselves engage in practices and have experiences and attachments that exist simultaneously across spatial and institutional boundaries: they are trans-local and transnational (Glick Schiller et al, 1992). Analogously, a transnational rationale of belonging supports the governance of migrants' rights, conceived and practiced across and between geographic and state boundaries, not through demarcations of ethno-cultural homogeneity or spatial proximity. There are global and regional institutions that establish social norms and legal rules on rights that transcend particular residence, citizenship or ethnocultural identification (Soysal 2012; Faist 2009, 2014). Typically these include transnationally regulated rights to express family ties; earn and access benefit entitlements; not be doubletaxed; secure long-term circular mobility across boundaries. In practice, transnational rationales of belonging overlap and can contradict those to which migrants are subject in different places simultaneously (Shaw and Miller, 2013; anonymised citation). Governing transnational belonging in practice can produce contingent and indeterminate rules of who belongs where, what Anna Amelina (2016) calls 'regimes of intersection'; gendered, classed and ethnicised inequalities shaping the form and limits of transnationalism.

These rationales of belonging are contingent and interlocking, and the synthesis presented here is unlikely to offer a globally exhaustive list. And of course, the supposedly territorially and ethnically coherent 'national' welfare states of Europe have always used discontinuous territorial, racial and ethnic boundaries to subjugate the belonging of colonized peoples, and those of ethno-religious and ethno-linguistic minorities. Values and attitudes towards the status, membership and rights of migrants and citizens are unlikely to generate only binary divisions. These conceptual discussions of belonging suggest that specific combinations of 
rationales are brought to bear to politically justify who has rights, when, where and under what conditions in particular cases. Before we turn to our empirical analysis, however, we first explain our research context and methodology.

\section{Research context, design and methodology}

Intra-EU migration is a good test case to explore how transnational social rights of migrant workers are established, protected or limited. From 2004-2013, reforms to the European Union Treaty and Regulations seemed to usher in a constitutionalised and normatively agreed, transnational right to mobility, that was also seen as an essential tool in promoting the EU's economic growth. The Union could be, and was, seen as a geo-economic, socio-political and institutional space in which EU citizens derived rights as legally constituted 'citizens'. Since then, however, politics and policy have shifted. Our empirical exploration examines the reasonings of policymakers at a key political turning point.

Our empirical interest was in the framing and rationales for the social security rights of migrants, rather than the practice of regulations and their implementation (which would have warranted interviews with, or observations of, ground-level decisionmakers). As such, we sought participants for their senior professional role, and experience of working in this transnational EU space, while also acting as 'translators' (Clarke et al 2015) of policy rationales into national policymaking. Between December 2014 and May 2015, we conducted 12 one-to one elite interviews with national policy stakeholders in the UK (seven interviews) and Poland (five interviews), who were working in the field of EU social security co-ordination. The interviews were conducted as part of a wider project across eight EU member states, that also involved regulatory analysis, survey and migrant interviews (Amelina et al, 2019). For the wider project, participants in a further six EU member states were selected and interviewed (by other researchers) on the same basis (detailed discussion in Runfors and Fröhlig 2019). ${ }^{1}$ We do not refer to these interviews in the remainder of the paper.

Our participants were all active in national and EU policymaking at a senior national and European level. Most were senior civil servants from relevant ministries (e.g. health, family, social security) as well as public social security lawyers and academics with an official policy advisory role (e.g. on ministerial or EU expert committees). A number of interviewees were also, or had been, their national representative on EU committee of member states responsible for designing regulations of social security in the European Union, and for offering national expert advice on implementation in their national context. One participant in the UK and one in Poland also had explicitly ideological roles, involved in politics and/or political campaigning, rather than only in policymaking. Most EU member states have only one national team in each ministry (sometimes only one team overall) negotiating with the EU on these issues. In the EU itself, social security co-ordination is considered a highly specialist 'technical' field, and this constitutes a small, expert and elite population with very limited heterogeneity. As such, the participants in the study constitute a relevant and, despite the small overall numbers, appropriate, purposive 'criterion' sample (Bryman 2016) ${ }^{2}$ to explore the rationales and reasoning that underpin particular social security regulations and their translation between EU and member state and between member states. 
The interviews were inductively oriented towards exploring participants' general interpretations, experiences and understandings of EU regulation of social security rights of free movers and its intersection with their national context. The topic guide used widelyframed, open-ended questions to explore participants' understandings of their national welfare system, and the social security rights of migrants as well as the role of the EU (see appendix 1). The topic guide was designed by Emma Carmel, with Ann Runfors, in English, and translated into Polish by Bożena Sojka. Interviews referred to in this paper were conducted in English and Polish respectively, by the authors, and lasted between 40 minutes to 1.5 hours. The analysis was conducted in each language by a native speaker, to ensure that specific meanings and nuance could be properly explored, and the Polish interview excerpts translated at a late stage in the analysis (cf Carmel 1999).

We performed qualitative thematic analysis of interviews, using open coding, creating categories for each language-set of interviews. In the open-coding phase, we attended particularly to the discursive framings, terminology and forms of argumentation adopted by our participants when they reflected on the characteristics, origins and development of free movement and social security co-ordination, the EU as a whole, its policy and law-making. This coding process was followed by comparison and coding across the English and Polish interviews to identify common framings and key vectors of difference among all participants. ${ }^{3}$ It was in the process of comparison in particular, that we were able to inductively identify specific forms of reasoning that participants used when interpreting their national regulation of EU migrants' social security rights, access and entitlements. We then iteratively explored alternative conceptualisations of these ways of reasoning with reference to social policy and migration literatures described above. In this article, we focus on explaining the distinct, substantive lines of reasoning, and framings of policy issues, that we identified among participants.

The timing of political events was important. The Polish parliamentary election in 2015 meant that gaining access to Polish participants became very difficult. When the interviews were conducted, the new government had introduced a major family benefit reform, which featured prominently in interviews. Our first UK interviews were conducted during Prime Minister David Cameron's negotiation with the EU in 2014-15. This period also saw 14 amendments to UK social security and welfare regulations for EU migrants. In our first five UK interviews, participants focused on the negotiation agenda of the Cameron government, and in the last two, "Brexit" featured strongly. In this febrile atmosphere it is very likely that, had we interviewed politicians and political advocates, we might have identified more marked discursive lines of difference among participants. As predominantly elite policy/legal professionals, our participants were articulate, extremely knowledgeable and politically selfaware. Given that only two of the participants had a specifically ideological stance, it is perhaps unsurprising that the others presented themselves, their professional role and their discourse as 'technical'; as regulatorily, legally and politically neutral. This is not to say, however, that politics was absent from the interview discussions. Indeed, the self-conscious positioning of these policy, regulation and legal professionals as moderate and/or nonpolitical, generated insights into what attributes of free movement, social security rights of 
EU migrants, and their regulation, constituted unspoken assumptions, distinct from those aspects available for contestation and debate.

The remainder of the article explains our findings for each national case, before discussing our transnational findings and their implications for the development of a new conceptual framework.

\section{Rationales of belonging and position in Polish policy expert narratives}

\section{Transnational context: Poland in the European Union}

Our interviewees' narratives positioned emigration as an inevitable, quasi-natural phenomenon that emerged directly from Poland's status as an EU member state in which the economic hierarchies of member statehood are inevitable; not available for political control or government (cf Sojka and Saar, 2020).

This [post 2004 migration] was a consequence of peoples' rational decisions... ...So, if we are joining the EU, and this is linked with free mobility of workers, so they make their decisions. [National advisory committee (NAC) member (2)]

Given this individual and rational choice, the country of origin is not responsible for migrants' social security, rights, or belonging. At the height of politicisation of the European Union's 'refugee crisis', Poland was positioned as a country of emigration, with consequent demographic problems, and, as an economically developing EU member state of inward migration, with a need to 'have control over the number of [Belarussian] Gastarbeiters' [NAC member (1)]. This framing of the transnational political economy and regulatory context enabled our policy experts to navigate three entangled rationales of belonging and establish hierarchies in the rights of citizens, 'migrants' and returnees.

\section{Ethno-cultural rationale}

The dominant rationale of belonging expressed among our interviews in Poland was ethnocultural. While distancing themselves, as rational and elite policy experts, from discourses that viewed emigrants as 'traitors', this 'most extreme' position was central to the political context within which they worked. Participants articulated a highly-developed but apparently moderate or reasonable, rationale of ethno-cultural belonging.

In this semi-distancing articulation, emigrants were Polish nationals who did not belong, because they did not fulfil their duties as Polish citizens in Poland. Polish emigrants are unable to reproduce the ethno-nation and consequently pass on cultural values. These reasonings co-existed with an expressed utilitarian need for immigration, of particular preferred kind, as a response to aging society, mentioned by all participants and typically expressed in the excerpts below. 
...mainly young people of reproductive age emigrate, which deepens the demographic problem in our country. People who could improve this situation have kids abroad. [EU Committee member]

[T]he good characteristic of immigration is that Ukrainians are relatively close to us in terms of, and here I will use all politically incorrect wordings: race, faith, religion.. [NAC member (1)]

Now Ukrainians are cheap labour in Poland, because also in Poland, lets not deny it we need workers [...] and they are unproblematic as they are like us. [Government official (1)]

Migration from Ukraine is not a problem at all. We are like brothers [Government official (2)]

In this context, and as expected from the literature, this ethno-cultural rationale was strongly gendered. On the one hand, Ukrainian immigrants are workers, men, brothers. On the other hand, women Polish emigrants are perceived as problematic. They are unable to reproduce the 'nation' and pass on the necessary ethno-cultural values.

Polish women prefer to have children abroad... But this is huge loss for Poland and for future of Poland. These children will not have Polish roots, Polish culture, and will most probably never be back, so they are lost for us. [NAC member (1)]

Ethno-cultural belonging is both presumed, and responsibility for nationhood is conventionally assigned to mothers. However, it is also not presented as being only a matter of ethnic 'Polish' identification: it also concerns presence in Poland.

\section{Temporal-territorial rationale}

Family and nation were closely tied, but discussion of children and returnees also highlighted a strong territorial dimension to migrants' belonging, rights and social security. Heternormative, married couples with children - 'the family' - were the fundamental unit of nation, reflecting strong traditions of Social Catholicism. But according to the temporalterritorial rationale, Polish migrant children, especially those born abroad, would not return to Poland as ethno-nationally 'Polish'. Weakening family ties associated with emigration are a cause of 'Euro-orphanhood' and 'multiple pathologies' [Expert EU Committee member], of 'broken families, or issues related to demography and so on' [National advisory committee member (1)].

It was not that presence in Poland was required, but rather that the longer you are away, the less you belong. In the transnational context of EU social security regulation and migration patterns, Poles resident in another EU member state were not Polish, and so not responsibility of the Polish national state. Discussing UK policies to check rights of residence of migrants who were turning 16 , one participant said: 
How could they suddenly be denied a right to reside? They don't have anything to do with Poland. ... they do not have roots in Poland anymore... if the whole family lives in the UK and they do not have any ties with Poland, then they are under British jurisdiction [...]. [Government official (1)]

The same interviewee also explained how the regulatory assessment of temporal-territorial belonging discriminated between the 'genuine'/non-genuine Polish resident, where genuineness was determined by physical, territorial presence:

...resident registration is not the same as residency. So, for example people have been in the UK for the last couple of years, but are still registered in Poland. So here we will introduce the verification of their actual residency.... because resident registration is often a sort of tie with Poland, but it is just an administrative tie. [Government official (1)]

Presence, however, was also sometimes not enough, as interviewees discussed behavioural, welfareist conditions to belonging, which also mediated the dominant ethno-cultural rationale.

\section{Welfareist rationale}

Our interviewees expressed classed and ethnicised hierarchies of migrant returnees, inferring an apparently obvious likelihood that returnees to Poland would be engaged in 'benefit tourism'. Preferred returnees would be successful, self-sufficient entrepreneurial individuals who do not pose a burden on the Polish social security system:

..well for example, if they set up some type of business here, and they will be self-employed, if they have money, yes, then they will be covered by insurance. Of course others can try to register as unemployed [...]. I don't think returnees have problems here, unless they create them themselves. [Government official (2)]

The naturalised context of emigration as an economically rational individual decision meant that decisions to return were equally seen as an individual responsibility for personal success or failure. Re-incorporation into the Polish social security system is seen as unproblematic for those with savings and/or entrepreneurs who belong through their re-incorporation in the local labour market. This also subtly positions Poland as a European country, structurally embedded in transnational systems of social stratification where it is undesirable to rely on welfare state. Mediating the temporal-territorial rationale of belonging, the longer a migrant was absent from the Polish labour market, the less (s)he belonged to it. "Benefit tourism" arguments were used to denigrate and discursively exclude returning nationals.

...from research we can see that employers do not value returnees too much. ...Often returnees are described as: oh you came back, so maybe you failed, why did you come back? [NAC member (2)] 
I mean they might be a problem. Why? The Polish health system isn't a universal health insurance....It's not based on Polish citizenship, ...it is not enough to be Polish to be insured. [Government official (2)]

Discussion of the new family benefit, 500+, a categorical benefit associated with pro-natalist, heteronormative social Catholic norms, was also marked by strongly welfareist attitudes that were directly articulated with the dominant rationale of ethno-cultural belonging. Its introduction was viewed as a potential tool to reduce emigration:

...if someone has two or three kids then this benefit starts to be comparable with the British one, and the cost of living in Poland is lower. So I don't think this will make people return, but it might prevent some form of migration. [Government official (1)]

Overall, shared cultural values and (particular preferred kinds of) family ties provided a basis for ethno-cultural belonging expressed by our participants, but this dominant rationale was qualified by the importance of being physically resident in Poland. According the temporalterritorial rationale, absence in particular diminished family ties, and challenged belonging to the nation. Yet, even temporal-territorial rationales were qualified by welfareism, once questions of access to resources were raised.

\section{Rationales of belonging and position: politicising rights and EU mobility in the UK}

\section{Transnational context}

The UK participants articulated a political regulatory context marking out British exceptionalism compared to other EU member states (also Runfors and Fröhlig 2019). One expert explained the dynamics in relevant EU meetings:

... [other Member States] sit there looking at the UK as a kind of voice of Europe ... and you know everyone is really keen for the UK to get involved ...hmmm [we] bring a lot to the table.

[technical expert from Ministry A].

The UK was represented as a leader - 'ahead' with welfare reforms; a 'driver', 'at the cutting edge' [ministry technical expert (1)], where other member states 'have an interest in what the UK is doing' [Government official (1)]. Other member states are thus 'behind' in a temporalized hierarchy of member statehood. While a focus on 'the big issues' positioned Britain as significant as and politically capable, 'we are often a bit of a trouble maker' [Ministry technical expert (1)]. This positioning was linked to naturalized differences among EU social security systems in which the UK was a special place with a unique welfare system (sometimes described inaccurately):

it isn't the most open in terms of eligibility and the fact that it's not tied to contributions in any meaningful way makes it unique. [Think tank director] 
....all our benefits are residency based, and .... the [EU] Regulation started off in six countries as an insurance-based scheme. The way in which coordination works it doesn't necessarily fit with the UK benefits regime. [Government official 2]

Narratives of uniqueness were articulated with accounts of the changing nature of the EU. All interviewees talked about the EU as a valuable political project, that sometimes verged on transnational rationale of belonging - for example, contributing to 'pan-European culture' and 'the enhancement of our quality of life' [Advisor to ministry X]. Yet the situation for the UK was problematic due to enhanced mobility and changes in the Union itself. In contrast, intraEU migration post-2004, was seen as contributing to the increasingly complex and unmanageable coordination of social security rights, an idea also used to challenge the EU as a political project.

\section{Welfareist rationales}

Across their accounts, participants reproduced a wider political narrative around 'welfare reform'. The prominence given to 'welfare reform' signalled the UK's uniqueness, being 'ahead'; essentialised as a country of 'principles'. 'Fairness' was the key principle that justified welfare reforms, and 'fairness' was a crucial condition for determining belonging (not only in the UK: Runfors and Fröhlig 2019). Discussing the benefit restrictions introduced in 2014-15, one participant declared:

I'm assuming all these measures save money, probably millions, but being in the UK, I think the public likes fairness and principle, and that's probably the primary driver. [Ministry technical expert (1)]

Another participant observed that 'I don't think that there is an accurate assessment of how much money is being saved' [NAC member]. Yet even if social security expenditure on EU migrants is relatively insignificant, it raised questions of fairness for hard-pressed British citizens, given the entitlements of EU citizens.

[...] like with everything in the UK, it is a lot of...you know like people caring about the principles [...] it is about what's right, especially when we are in austerity. [Government official (2)]

It's not just a kind of matter of money it's a matter of kind of principle and citizenship, or else then I'd say the system is broken. [Think tank director]

These elite policy experts did not engage directly with benefit tourism arguments; they were aware that there is little evidence of the 'undeservingness' of EU migrants as 'benefit tourists'. As in Poland, our participants deliberately referred to more 'extreme' but important political reference points to legitimize the reasonableness of their position. What migrants deserve in social security, and under what conditions, was re-framed as determined by this 
incontestable but elusive quality of "fairness", expressed as a question of the relationship between migrants and citizens.

the majority of that [migration] comes from the EU because we no longer take low skilled migrants from elsewhere pretty much. And I think there is an issue around fairness which is again access to social security [...] [Think tank director]

Well it would mean that we would have to pay people with their right to residence, child benefit and child tax credit. So yes and I don't think this would make a very good Daily Mail ${ }^{4}$ article [laughing]. [Government official (1)]

This welfareist rationale of belonging established a moral economy where being fair, rather than equitable, solidaristic, or deserving is the principle of welfare and social organization (also between EU member states; Runfors and Fröhlig 2019). Being 'fair' marked the outer limit of what can be done for those who do (and do not) belong. 'Fairness' expressed and justified the intensification of conditionality, and the non-provision of welfare. To have a need or entitlement to welfare was itself an indicator of not-belonging.

\section{Labourist rationale}

Trying to secure the need for an appropriately skilled and willing workforce within the UK economy from wherever those workers come sits awkwardly with a political discourse which says foreign workers are taking British jobs, foreign workers are taking social security benefits to which they should not be entitled.....[NAC member]

In the labourist rationale of belonging in the UK, work, and work of particular kinds, was a key marker of difference that might mediate the 'disentitlement' of welfareist 'non-belonging' in the UK, between those who have rights and those who do not. Yet the distinction between 'British' and 'European' workers acted as a supplementary ethnicised marker of degrees of belonging, to nuance and qualify the welfareist rationale focused on migrants. The labourist rationale reproduced classed assumptions about work and welfare in the UK that positioned the unemployed and migrants as not exactly equivalent non-citizens (Soysal 2012, Anderson, 2013). Our participants understood that EU migrants do not disproportionately claim any benefits, including unemployment benefits: 'we have only few thousand people [claiming benefit] but we have probably 10 times this money being brought in. .... I guess it's important that most people are coming to work.' [Ministry technical expert (1)].

However, migrants were importantly stereotyped as workers taking low-skilled 'natives" jobs. This was in part a straightforward labour-protectionist argument, where (ethnicised, gendered and classed) 'native' workers need jobs: migrants are seen as posing a threat by undercutting wages, by working too hard, or just being too numerous. This finding reflects wider discussion on selectivity for skill in migration governance, with quasi-magical qualities ascribed to highpaid work, and classed and gendered values about which jobs should provide a pathway to social membership and rights (Paul, 2015; Kofman, 2013; O’Brien 2016). 
There are also debates around that there are a lot of people coming across, highly skilled people doing low skilled work in the United Kingdom, and that affects the targeted support [for British unemployed]. [...] [Government official (2)]

In addition however, the presence and rights of employed EU migrants were further problematized when combined with the welfareist rationale. When migrants undertake lowskill and low-paid employment, the 'failed citizen' [British unemployed] (Anderson, 2013) is inappropriately shielded from the state's project of 'targeting' support in order to change their problematic behaviour (being unemployed). The 'hard-working' EU migrants who perform to the labourist rationale of belonging, were problematic because they were doing the wrong kinds of (low skill, low paid) employment, and so facilitating 'welfare dependency' of the 'British' unemployed. Combining welfareist and labourist rationales meant that EU free movers are accused of both 'stealing jobs' and also of abusing welfare system by claiming benefits.

\section{Temporal-territorial rationale}

The politics of temporal-territorial belonging were central to arguments for ending free movement, many of the social security regulation reforms in 2014-15, and negotiations to and determine the 'best' arrangements for rights and privileges of EU migrants in the UK.

EU regulations permit a three-month moratorium on free movers' access to non-contributory welfare benefits and services (housing benefit, child benefit). Before the 2014 reforms, this possibility had not been invoked in the UK. '[W]e don't have many people taking unemployment benefit out, so using that three months' [Government official] moratorium did not save money (as per welfareist rationale) or incentivise contributory employment (as per labourist rationale). Yet in the contentious context of pre-referendum politics, the temporalterritorial rationale provided an opening for negotiation in the wider EU. So, welfareist rationales of belonging became significantly qualified by territorial belonging; working is not enough, working over time was important.

However we think there has to be kind of a close tie between nationality and access to the national public purse, because of where the money comes from. [Think tank director]

This rationale was expressed most directly in discussions of child benefit, perceived as particularly problematic. ${ }^{5}$ Even when participants dismissed or denigrated arguments that dominated public/media discourse, the need to be 'here' was important than familial relationships with the hard-working EU migrant who otherwise had entitlement to child benefit. The child (living abroad) did not have the residential relationship of belonging that would entitle them - or rather their UK-resident parents - to benefit. This was, as ever, linked to the dominant rationale of welfareism and 'fairness', concerned with the higher value of this benefit in countries where the cost of living was lower than the UK. 
these children are much better off living in another member state receiving huge amount of support from the United Kingdom [sarcastic laugh]. [Government official (1)]

so I guess lots of Polish plumbers to be stereotypical getting child benefit for their children back in Poland...and then suddenly it becomes ...this is now like a Conservative party manifesto commitment. [...] [Ministry technical expert (1)]

\section{Discussion}

Across our two cases, we identified four rationales of belonging - ethno-cultural, temporalterritorial, welfareist and labourist - two of which were used in both country cases. These rationales were used implicitly or explicitly to scaffold argumentation for the exclusion of specific categories of migrant from accessing benefits (e.g. returning national citizens who had grown up elsewhere), for the hierarchical privileging of social rights for some EU migrants over others.

Highly relevant to wider literature on attitudes and deservingness, is our finding that rationales of belonging were made sense of by reference to their positioning in the wider political economy of migration in the EU (also Paul 2014). For example, Poland's experts articulated this rationale in negative terms, where (un)belonging was marked by length of absence, as a self-identified country of emigration. In the UK, this rationale was articulated by participants in positive terms, belonging was marked by length of presence in the UK, as a selfidentified country of immigration. Table one summarises our empirical findings from across our interviews.

The four rationales of belonging expressed by our participants- were woven together by participants to create distinctive vectors along which it was assumed that migrants should be able to secure belonging, rights and social protection as they move between countries. In each of our cases, there were distinct dominant shared rationale, mediated by two others. So, in the UK case, the dominant welfareist rationale was qualified by requirements for territorialtemporal belonging of migrants, and ethno-national rationales of belonging are subordinate to classed markers of belonging (welfareism). In case of our Polish participants, the dominant rationale for identifying those who have social membership, was ethno-cultural, but this is mediated by gender, temporal-territorial absence, and classed welfareism. We did not find an expression of a transnational rationale of belonging in either case. This is perhaps unsurprising, given the national policy positions held by our participants. It is probable that transnational rationales are more likely to be found among those circulating particular party political positions and/or policy professionals in international organisations.

Table 1: Comparing rationales of belonging among policy experts in Poland and the UK 


\begin{tabular}{|c|c|c|}
\hline \multirow{2}{*}{$\begin{array}{l}\text { Transnational } \\
\text { context }\end{array}$} & Superordinate status. & Interpellated status. \\
\hline & Country of immigration. & $\begin{array}{l}\text { Country of emigration; } \\
\text { immigration. }\end{array}$ \\
\hline \multirow{2}{*}{$\begin{array}{l}\text { Dominant } \\
\text { rationale }\end{array}$} & Welfareist & Ethno-cultural \\
\hline & $\begin{array}{l}\text { Ethnicised protection of welfare and } \\
\text { public service resources. }\end{array}$ & $\begin{array}{l}\text { Gendered expectation of ethno-national } \\
\text { loyalty, identity and culture. }\end{array}$ \\
\hline \multirow{4}{*}{$\begin{array}{l}\text { Subordinate } \\
\text { rationales }\end{array}$} & Territorial-temporal & Territorial-temporal \\
\hline & $\begin{array}{l}\text { Positive: presence over time leads to } \\
\text { acquisition of belonging \& rights. }\end{array}$ & $\begin{array}{l}\text { Negative: absence over time leads to loss } \\
\text { of belonging \& rights. }\end{array}$ \\
\hline & Labourist & Welfareist \\
\hline & $\begin{array}{l}\text { Classed and ethnicised performative } \\
\text { work-based conditions for social } \\
\text { membership }\end{array}$ & $\begin{array}{l}\text { Ethnicised and gendered provision for } \\
\text { 'one's own', based on performative } \\
\text { economic success for belonging on return. }\end{array}$ \\
\hline
\end{tabular}

\section{Conclusion}

In this article, we have explored how the 'intentionality of control' (Anthias and Yuval Davis, 1989 ) in the politics of belonging can be organized, reasoned and expressed to generate specific political rationales of belonging for migrants, and in doing so, articulates their rights, and their limits. So what of our wider contention on the value of using rationales of belonging as a new conceptual framework? We venture the following conclusions.

The framework of 'rationales of belonging' is promising because it is simple, clear, and flexible, but not naïve or ambiguous. It (so far) suggests a number of possible rationales, and our small study shows that rationales can be combined in different forms. Our analysis indicates that political and regulatory distinctions are shaped by the presumed social group, migration biography, legal status, and benefit category of the claimant. The construction of ethnic, gendered, and classed hierarchies is produced by the articulation of specific rationales of belonging with direct reference to the wider purposes of policy. Rationales of belonging are not just exclusionary (cf 'deservingness'): they are selective and positional. A 'rationales of belonging' framework can explicitly address questions of racism and xenophobia and how they are hidden within, or used to re-work, related but separate ideas of membership, belonging and rights.

Furthermore, our framework enabled us to show that there are rationales that are expressed in different places simultaneously, but that negate, rather than promote, transnational belonging. Indeed, these shared rationales can transnationally exclude migrants from entitlement in twice-over, and that some migrants are more likely to face this than others (anonymised citation). In our empirical example, this combination of welfareist and temporalterritorial rationales shared in Poland and the UK, expresses an underlying rejection of the ordinariness of migrants' lives. For even these 'free moving' EU citizen migrants, an ordinary contingent biography - divorce, death, accident, debts, and ill-health - does not trigger access 
to entitlement and resources. Instead, facing regulations organised around exclusionary rationales of belonging in places of origin and of destination, such ordinary events trigger disentitlement to resources, including work, housing, health, education and care; even residence itself. The effect, translated into regulation, of these shared exclusionary rationales, is transnational un-belonging.

Finally, this approach draws attention to wider transnational relations of political economy and power in shaping the political discourse and framing of migration governance. Rationales of belonging justify selectivity and complex stratification (Carmel and Paul 2013) by strategically positioning the national state, welfare system and migration in a wider political economy context (also Paul 2013). In our empirical case, both sets of participants represented a commonly-understood national regulatory context in an EU framework. We can imagine that in other cases, neo-colonial, dependency or partnership contexts might be particularly salient. Both the importance, and the expression of, relational positioning of national regulations in our study constitutes a promising avenue for research.

The conceptual ambiguity of 'welfare chauvinism' reflects and contributes to the continued political resonance of assumptions about the existence of 'welfare magnets', and 'benefit tourism' (Geiger, 2018; Greve 2019). These assumptions continue to exert their elusive, almost magical power over policymakers, politicians, and academics as a way of politically reasoning about, and regulating, migrants and their rights, in a reductionist 'policy imaginary' (Mayblin 2016). Yet all available empirical evidence contradicts this argument, is ambiguous, or just poorly framed and conceptualised (Greve 2011; Carmel and Sojka 2018). We need better analytical tools to discriminate between racism, anti-immigrantism, xenophobia, labour-market and welfare-state protectionism. We think that the framework developed here should help to explain how these function together to shape the politics and governance of migrants rights in practice.

\section{BIBLIOGRAPHY}

Amelina, A. 2016. Transnationalizing Inequalities in Europe. Sociocultural Boundaries, Assemblages and Regimes of Intersection, London: Routledge.

Amelina, A. and Lutz 2019. Gender and Migration Transnational and Intersectional Prospects. London: Routledge.

Amelina, A., Carmel, E., Runfors, A. and Scheibelhofer, E., 2019. The Boundaries of European Social Citizenship. London: Routledge.

Andersen, JG \& Bjørklund, T. 1990. Structural Changes and New Cleavages: The Progress Parties in Denmark and Norway', Acta Sociologica 33(1): 195-217

Anderson, B. 2013. Us and Them? The dangerous politics of immigration control. Oxford, Oxford University Press.

Anthias, F. and Yuval-Davis, N., 1989. Woman-nation-state. Springer. 
Anthias, F. and Yuval-Davis, N., 2005. Racialized boundaries: Race, nation, gender, colour and class and the anti-racist struggle. London: Routledge.

Ataç, I. \& Rosenberger, S. 2019. Social Policies as a Tool of Migration Control, Journal of Immigrant \& Refugee Studies, 17(1): 1-10

Bruzelius, C. 2019. Freedom of movement, social rights and residence-based conditionality in the European Union. Journal of European Social Policy, 29(1), 70-83.

Cerami, A. and Carmel, E. 2011. Governing migration and welfare: institutions and emotions in the production of differential integration. In Carmel, E., Cerami, A. and Papadopoulos, T. (eds) Migration and Welfare in the New Europe: Social protection and the challenges of integration, Bristol: Policy Press.

Carmel, E. 2019. Governance Analysis. Critical enquiry at the intersection of policy, politics and society. Cheltenham: Edward Elgar.

Carmel, E. and Paul, R., 2013. Complex stratification: Understanding European Union governance of migrant rights. Regions and Cohesion, 3 (3), pp. 56-85.

Carmel, E., and Sojka, B. 2018. Social Security and the Management of Migration in Millar, J., and Sainsbury, R. (eds.), Understanding Social Security (3rd ed.). Bristol: Policy Press.

Clarke, J. 2005. New Labour's Citizens: Activated, Empowered, Responsibilized, Abandoned? Critical Social Policy 25 (4): 447-463.

Ennser-Jedenastik, L., 2017. Welfare Chauvinism in Populist Radical Right Platforms: The Role of Redistributive Justice Principles, Social Policy \& Administration, 52(1), pp.293-314.

Faist, T. 2009. The Transnational Social Question: Social Rights and Citizenship in a Global Context. International Sociology, 24(1), 7-35.

Faist, T., 2014. On the transnational social question: How social inequalities are reproduced in Europe. Journal of European Social Policy, 24(3), pp.207-222.

Geiger B. B. 2018. Benefit 'Myths'? The Accuracy and Inaccuracy of Public Beliefs about the Benefits System. Social Policy \& Administration, 52(5): 998-1018.

Glick Schiller, N., Basch, L. and Blanc-Szanton, C., 1992. Transnationalism: A new analytic framework for understanding migration. Annals of the New York academy of sciences, 645(1), pp.1-24.

Greve, B. 2019. Welfare, Populism, and Welfare Chauvinism, Bristol: Policy Press.

Heindlmaier, A., and Blauberger, M. 2017. Enter at Your Own Risk: Free Movement of EU Citizens in Practice', West European Politics, 40(6): 1198-1217 
Jensen, C., \& Petersen, M. 2017. The Deservingness Heuristic and the Politics of Health Care. American Journal of Political Science, 61(1), 68-83.

Jørgensen, M. B., \& Thomsen, T. L. 2016. Deservingness in the Danish context: Welfare chauvinism in times of crisis. Critical Social Policy, 36(3), 330-351.

Keskinen, S. 2016. From welfare nationalism to welfare chauvinism: Economic rhetoric, the welfare state and changing asylum policies in Finland. Critical Social Policy, 36(3), 352-370.

Koostra, A. 2016. Deserving and Undeserving Welfare Claimants in Britain and the Netherlands: Examining the role of ethnicity and migration status using a vignette experiment, European Sociological Review, 32(3): 323-38.

Kremer, M. 2016. Earned Citizenship: Labour Migrants' Views on the Welfare State. Journal of Social Policy, 45(3): 395-415.

Mayblin, L. 2016. Complexity reduction and policy consensus: Asylum seekers, the right to work, and the 'pull factor' thesis in the UK context. The British Journal of Politics and International Relations, 18(4), 812-828.

Mayblin, L. 2019. Impoverishment and asylum: social policy and slow violence, Routledge.

Mewes, J. and Mau, S., 2013. Globalization, socio-economic status and welfare chauvinism: European perspectives on attitudes toward the exclusion of immigrants. International Journal of Comparative Sociology, 54(3): 228-245.

Osipovič, D. 2015. Conceptualisations of Welfare Deservingness by Polish Migrants in the UK, Journal of Social Policy, 44(4): 729-46.

Paul, R. 2013. Strategic Contextualisation: Free Movement, Labour Migration Policies and the Governance of Foreign Workers in Europe, Policy Studies, 34(2): 122-141.

Paul, R. 2015. The Political Economy of Border-Drawing: Arranging Legality in European Labor Migration Policies. Oxford: Berghahn.

Runfors, A. and Fröhlig, F., 2019. Discourses of Belonging in the Context of EU Enlargements: A Comparative Analysis of Policy Discourses Specifying EU Welfare Access. In Amelina, A., Carmel, E., Runfors, A. and Scheibelhofer, E., (eds) The Boundaries of European Social Citizenship. London: Routledge

Sainsbury, D. 2012. Welfare States and Immigrant Rights: The Politics of Inclusion and Exclusion. Oxford: Oxford University Press.

Shaw, J., and Miller, N. 2013. When Legal Worlds Collide: An Exploration of What Happens When EU Free Movement Law Meets UK Immigration Law', European Law Review, 38(2): 137166. 
Shutes, I. and Walker, S., 2018. Gender and free movement: EU migrant women's access to residence and social rights in the UK. Journal of Ethnic and Migration Studies, 44(1), 137-153.

Schneider, A. L. and Ingram, H. M. 2005. Deserving and entitled: social constructions and public policy. Albany, State University of New York.

Sojka, B. and Saar, M. 2020. Returnees: Unwanted Citizens or Cherished Countrymen, Social Policy Review. Bristol: Policy Press.

Soysal, Y.N. 2012. Citizenship, Immigration, and the European Social Project: Rights and Obligations of Individuality, British Journal of Sociology, 63, 1-21.

van Oorschot, W., Roosma, F., Meuleman, B. and Reeskens, T. eds., 2017. The social legitimacy of targeted welfare: Attitudes to welfare deservingness. Cheltenham: Edward Elgar.

Yuval-Davis, N., 1996. Women and the biological reproduction of "the nation". In Women's studies international forum, 19(1-2): 17-24.

Yuval-Davis, N. 2011. The politics of belonging: Intersectional contestations, London, Sage.

\footnotetext{
${ }^{1}$ The interviews were conducted as part of the NORFACE-funded TRANSWEL project (www.transwel.org). This section of the project was led by Ann Runfors and Florence Fröhlig at Södertörn University. We are grateful for their insights and inspiration in developing our analysis of the UK-Poland case, and the opportunity for collective reflection on the analysis with other TRANSWEL researchers. As explained below, the method of analysis for this article differs from that of the TRANSWEL project (cf Runfors and Fröhlig 2019), but consideration of our interview findings draws on these discussions.

2 The small size of this specialist and elite group, a number of whom (from different countries, as well as the same country) may work with one another, meant that protecting anomymity was potentially difficult. For this reason, we asked participants to identify a role description for themselves that we could use when citing them, that were confident would also protect their anonymity. The roles of participants published here are those chosen by participants.

${ }^{3}$ For the TRANSWEL project, this article's authors undertook critical discourse and discourse logics analysis to identify the logics that underpinned discourses on EU migration and welfare, to inform Runfors and Fröhlig's comparative analytical synthesis across eight EU member states (2019). Our purpose differs: to conceptualise reasonings about the governance of migrants' rights, by exploring their expression in a small case study.

${ }^{4}$ The Daily Mail is a British daily conservative tabloid newspaper, notorious for shaping political discourse and debate as politicians try to please its (notional) readers.

5 This was also part of a campaign by the Netherlands, Austria, Germany and the UK from November 2013, to change the regulation on child benefit, which has continued to garner support among member states even during protracted Brexit negotiations.
} 